\title{
PENENTUAN EFISIENSI INHIBISI KOROSI BAJA MENGGUNAKAN EKSTRAK KULIT BUAH KAKAO (Theobroma cacao)
}

\author{
Sri Hermawan, Yuli Rizky Ananda Nasution, Rosdanelli Hasibuan \\ Departemen Teknik Kimia, Fakultas Teknik, Universitas Sumatera Utara, \\ Jl. Almamater Kampus USU Medan 20155, Indonesia \\ Email: sri_hermawan@students.usu.ac.id
}

\begin{abstract}
Abstrak
Ekstrak kulit buah kakao merupakan inhibitor alami yang dapat digunakan untuk menghambat laju reaksi korosi. Penelitian ini diawali dengan mengekstraksi kulit buah kakao dengan cara maserasi kemudian dilanjutkan dengan evaporasi pada rotary vacuum evaporator dan ekstraknya digunakan sebagai inhibitor dengan konsentrasi 600,800 dan 1000 ppm, dengan sampel uji korosi yaitu baja dengan ukuran $1 \times 2 \mathrm{~cm}$ dengan ketebalan $0,1 \mathrm{~cm}$ dan media korosif air laut, air hujan dan asam sulfat 1M. Efisiensi inhibisi tertinggi yang dihasilkan adalah 93,06 \%, dengan konsentrasi inhibitor 600 ppm dalam media korosif air hujan; yang berarti bahwa ekstrak kulit buah kakao lebih efisien digunakan pada media korosif air hujan.
\end{abstract}

Kata kunci: kakao, maserasi, media korosif, efisiensi inhibisi

\begin{abstract}
Abstrak
Cocoa peel extract is a natural inhibitor that can be used to inhibit the corrosion reaction rate. This research begins by extracting cocoa pods by maceration followed by evaporation on rotary vacuum evaporator and extracts used as the inhibitor with concentration 600, 800 and 1000 ppm, using steel $1 \times 2 \mathrm{~cm}$ and the thickness is $0,1 \mathrm{~cm}$ to determine the corrosion rate and corrosive medias are sea water, rainwater and sulfuric acid $1 \mathrm{M}$. The highest inhibition efficiency generated is $93,06 \%$ with concentration of 600 ppm inhibitor in rainwater corrosive media; which means that cocoa peel extract more efficiently used in rainwater corrosive media.
\end{abstract}

Keywords: cocoa, maceration, corrosive media, inhibition efficiency

\section{Pendahuluan}

Kulit buah kakao sebagai limbah hasil perkebunan sangat potensial dan merupakan komponen terbesar dari buah kakao lebih dari $70 \%$ berat buah masak [6] . Buah kakao dalam bentuk segar terdiri dari kulit buah $73 \%$, plasenta $2 \%$ dan biji $24,2 \%$. Kulit buah kakao belum dimanfaatkan secara optimal bahkan sebagian besar masih merupakan limbah perkebunan kakao karena hanya dikumpulkan pada lubang tertutup atau dibuang disekitar tanaman kakao, maka perlu dicari cara mengenai pemanfaatan kulit buah kakao yang lebih efisien dan memiliki nilai ekonomis yang lebih tinggi. Kulit buah kakao memiliki senyawa tannin yang cukup besar [5] . Hal ini menyebabkan dimungkinkannya pemanfaatan kulit buah kakao sebagai inhibitor alami pada reaksi korosi baja. Perumusan masalah dalam penelitian ini adalah bagaimana pengaruh penambahan ekstrak kulit buah kakao terhadap laju reaksi korosi pada baja dan bagaimana efisiensi inhibisi ekstrak kulit buah kakao pada berbagai media korosif. Tujuan dari penelitian ini adalah untuk menghasilkan ekstrak kulit buah kakao yang mengandung tanin dan untuk mengetahui efisiensi inhibisi tertinggi dari ekstrak kulit buah kakao.

\section{Teori}

Theobroma cacao adalah nama biologi yang diberikan pada pohon kakao oleh Linnaeus pada tahun 1753. Tempat alamiah dari genus Theobroma adalah di bagian hutan tropis dengan banyak curah hujan, tingkat kelembaban tinggi, dan teduh. Buah kakao yang siap dipetik adalah buah kakao yang telah masak optimal ditandai dengan perubahan warna kulit buah yang semula hijau menjadi kuning (jenis Forestero) dan merah (jenis Criollo). Masaknya buah selain ditandai dengan perubahan warna juga bunyi nyaring apabila dilakukan pengetukan buah. Pada kulit buah kakao terdapat senyawa tannin.

Tanin merupakan komponen zat organik derivat polimer glikosida yang terdapat dalam bermacam-macam tumbuhan, terutama tumbuhan berkeping dua (dikotil). Monomer tanin adalah digallic acid dan D-glukosa dan memiliki rumus molekul $\mathrm{C}_{76} \mathrm{H}_{52} \mathrm{O}_{46}$. Ekstrak tanin terdiri dari campuran senyawa polifenol yang sangat kompleks dan biasanya tergabung dengan karbohidrat rendah. Oleh karena adanya gugus fenol, maka tanin akan dapat berkondensasi dengan formaldehida. Tanin terkondensasi sangat reaktif terhadap formaldehida dan mampu membentuk produk kondensasi, berguna untuk bahan perekat termosetting yang tahan air dan panas [7]. 
Maserasi merupakan proses perendaman sampel menggunakan pelarut organik pada temperatur ruangan. Proses ini sangat menguntungkan dalam isolasi senyawa bahan alam karena dengan perendaman sampel tumbuhan akan terjadi pemecahan dinding dan membran sel akibat perbedaan tekanan antara di dalam dan di luar sel, sehingga metabolit sekunder yang ada dalam sitoplasma akan terlarut dalam pelarut organik dan ekstraksi senyawa akan sempurna karena dapat diatur lama perendaman yang dilakukan [2] .

Korosi adalah kerusakan atau degradasi logam akibat reaksi dengan lingkungan yang korosif. Adapun beberapa cara dalam pengendalian proses yaitu dengan metode pelapisan, dengan proteksi katodik dan dengan penambahan [1] .

\section{Metodologi Penelitian Bahan dan Alat}

Bahan yang digunakan adalah kulit buah kakao sebagai bahan baku, sebagai zat pengekstrak digunakan etanol $70 \%$, baja $1 \times 2$ dengan ketebalan 0,1 sebagai sampel uji korosi, media korosif menggunakan asam sulfat $1 \mathrm{M}$, air laut dan air hujan dan sebagai indikator tanin digunakan larutan $\mathrm{FeCl}_{3}$ 1\%. Alat utama yang digunakan adalah rotary vacuum evaporator untuk proses evaporasi (penguapan), blender untuk menghaluskan kulit buah kakao sehingga menjadi serbuk simplisi. Neraca elektrik untuk menimbang dan oven untuk mengeringkan.

\section{Proses Pembuatan Serbuk Kulit Buah Kakao}

Kulit buah Kakao dibersihkan dari kotorankotoran, kemudian dirajang kecil-kecil dan dikeringkan di udara terbuka selam 3 hari. Kulit yang telah kering digiling hingga menjadi serbuk.

\section{Proses Ekstraksi}

Serbuk kulit buah kakao sebanyak 100 gr dimasukkan ke dalam maserator, kemudian dimasukkan etanol $70 \%$ sebanyak 1 L. Kemudian campuran diaduk dan dibiarkan di dalam maserator selama 5 hari, setelah 5 hari hasil maserasi disaring dengan menggunakan kertas saring, kemudian filtratnya dimasukkan ke dalam rotary vacuum evaporator pada suhu $54-55^{\circ} \mathrm{C}$ selam 1 jam. Hasil ekstraknya dimasukkan ke dalam botol coklat dan dilakukan analisa kualitatif apakah terdapat tannin.

\section{Analisa Kualitatif}

Ekstrak kulit buah kakao sebanyak 10 gr dimasukkan ke dalam beaker glass, kemudian ditambahkan air $10 \mathrm{ml}$ dan dipanaskan hingga mendidih. Setelah itu disaring dan diambil filtratnya, kemudian filtratnya ditambahkan $\mathrm{FeCl}_{3}$ $1 \%$ sebanyak 10 tetes, jika berubah warna menjadi biri atau biru kehijauan maka terdapat tanin.

\section{Persiapan Baja yang Akan di uji}

Sampel baja dengan ukuran 1 x $2 \mathrm{~cm}$ dengan tebal $0,1 \mathrm{~cm}$ dihaluskan permukaannya dengan ampelas. Permukaan yang telah halus ini dicuci dengan deterjen, dan aquades, kemudian dikeringkan dalam oven pada suhu $110^{\circ} \mathrm{C}$ selama 2 jam.

\section{Perendaman Baja dalam Larutan Media Korosif Tanpa Penambahan Inhibitor}

Sampel baja yang telah disiapkan masingmasing direndam dalam media korosif yaitu air laut, air hujan dan asam sulfat $1 \mathrm{M}$ selama 120 jam.

\section{Perendaman Baja dalam Larutan Media Korosif dengan Penambahan Inhibitor}

Sampel baja yang telah disiapkan masingmasing direndam dalam larutan campuran media korosif dan inhibitor selama 120 jam. Variasi konsentrasi inhibitor adalah 600, 800 dan 1000 ppm. Kemudian ditentukan laju reaksi korosi dan efisiensi inhibisi dengan menggunakan persamaan 1 dan persamaan 2

\section{Penentuan Laju Reaksi Korosi}

Setelah proses korosi berjalan selama waktu tertentu, produk korosi diangkat dari media korosi, dicuci dengan hati-hati dengan menggunakan sikat yang halus. Selanjutnya dikeringkan pada suhu kamar, kemudian ditimbang sebagai berat akhir. Berat awal dari baja adalah berat baja sebelum direndam kedalam larutan. Laju reaksi korosi dihitung dengan persamaan berikut :

Laju Reaksi Korosi $=\frac{\text { Berat Awal }- \text { Berat Akhir }}{\text { Luas Baja } \times \text { Waktu Perendaman }}$

\section{Penentuan Efisiensi Inhibisi}

Efisiensi Inhibisi $=\frac{\text { Vko }- \text { Vki }}{\text { Vko }} \times 100 \%$

Dimana $:$ Vko = laju reaksi korosi tanpa inhibitor Vki = laju reaksi korosi dengan inhibitor

\section{Hasil dan Pembahasan}

Laju reaksi korosi baja tanpa penambahan inhibitor yaitu : pada media kosrosif air laut laju korosinya sebesar $0,0387 \mathrm{mg} / \mathrm{cm}^{2}$.jam, pada media korosif air hujan laju korosinya sebesar 0,0235 $\mathrm{mg} / \mathrm{cm}^{2}$.jam dan pada media korosif asam sulfat 1 M laju korosinya sebesar $1,3692 \mathrm{mg} / \mathrm{cm}^{2}$.jam.

\section{Hubungan Laju Korosi - Konsentrasi Inhibitor}

Hubungan laju korosi terhadap konsentrasi inhibitor dapat dilihat pada gambar 1, dimana laju reaksi korosi yang diperoleh cenderung menurun untuk setiap kenaikan konsentrasi inhibitor. 


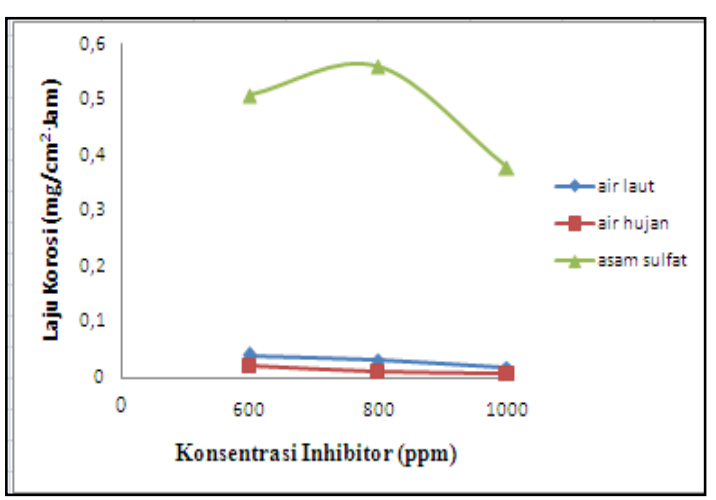

Gambar 1. Laju Reaksi Korosi Berdasarkan Konsentrasi Inhibitor

Laju reaksi korosi dengan adanya ekstrak kulit buah kakao dalam air laut, air hujan maupun air laut menurun jika dibandingkan dengan tanpa penambahan ekstrak. Hal ini disebabkan karena adanya senyawa tanin yang ada dalam ekstrak. Senyawa tanin dalam ekstrak dapat membentuk senyawa komplek dengan Fe(III) di permukaan logam [4], sehingga laju reaksi korosi akan mengalami penurunan. Senyawa komplek ini akan menghalangi serangan ion-ion korosif pada permukaan logam, sehingga laju reaksi korosi akan menurun. Walaupun ada titik yang mengalami kenaikan yaitu dalam media korosif asam sulfat 1 M pada konsentrasi inhibitor 800 ppm, hal ini disebakan karena lapisan Fe-tanin ekstrak tidak bisa menutupi seluruh permukaan baja, sehingga pada bagian yang tidak tertutupi $\mathrm{Fe}$ dapat terion dan mengalami korosi. Selain itu, ada pengotorpengotor pada tanin ekstrak yang menempel pada permukaan baja juga mempengaruhi cepatnya korosi [3] . Dengan demikian ekstrak kulit buah kakao dapat menghambat laju korosi baja, sehingga dapat dijadikan sebagai inhibitor dalam reaksi korosi pada baja.

\section{Hubungan Efisiensi Inhibisi - Konsentrasi Inhibitor}

Hubungan efisiensi inhibisi terhadap konsentrasi inhibitor dapat dilihat pada gambar 2, dimana efisiensi inhibisi cenderung menaik untuk setiap penambahan konsentrasi inhibitor.

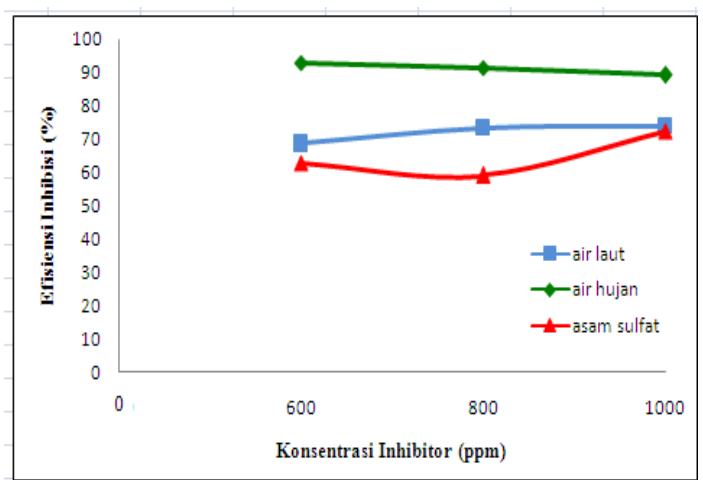

Gambar 2. Efisiensi

Inhibisi

Berdasarkan

Konsentrasi Inhibitor
Efisiensi inhibisi ekstrak kulit buah kakao yang dihasilkan berbeda-beda tergantung pada konsentrasi inhibitor dan media korosif. Pada grafik dapat dilihat bahwa efisiensi inhibisi pada media korosif air laut dapat mencapai $73,8 \%$ pada konsentrasi inhibitor 1000 ppm, efisiensi inhibisi pada media korosif air hujan dapat mencapai $93,06 \%$ pada konsentrasi inhibitor 600 ppm, efisiensi inhibisi pada media korosif air laut dapat mencapai $72,41 \%$ pada konsentrasi 1000 ppm. Efisiensi inhibisi tertinggi yang dihasilkan adalah pada media korosif air hujan dengan konsentrasi inhibitor 600 ppm, hal ini disebabkan karena pada kondisi tersebut senyawa kompleks Fe-tanin terbentuk dengan sempurna dan menutupi seluruh permukaan baja.

\section{Kesimpulan}

Kulit buah kakao dapat menghambat laju reaksi korosi pada baja, sehingga dapat dijadikan sebagai inhibitor alami dalam reaksi korosi.

Laju korosi menurun dengan bertambahnya konsentrasi inhibitor (ekstrak kulit buah kakao).

Efisiensi inhibisi tertinggi terjadi pada media korosif air hujan dengan konsentrasi inhibitor 600 ppm yaitu sebesar 93,06\%.

\section{Daftar Pustaka}

[1] Budiyanto, Pengendalian Korosi, Budisma. blogspot.com, 2011, diakses tanggal 02 Juli 2012.

[2] Efri Mardawati, Kajian Aktivitas Antioksidan Ekstrak Kulit Manggis (Garcinia Mangostana L ) dalam Rangka Pemanfaatan Limbah Kulit Manggis di Kecamatan Puspahiang Kabupaten Tasikmalaya. Laporan Akhir Penelitian, Universitas Padjadjaran, Bandung, 2008.

[3] Emriadi, Mekanisme dan Laju Reaksi Inhibisi Korosi Baja Oleh Tanin, Universitas Andalas, Sumatera Barat, 2000.

[4] Favre, The Influence of Gallic Acid On The Reduction of Rust on Painted Steel Surface, J.Corrosion Science 34, (1993) 1483-1492.

[5] Muliati, Reaktivitas Gugus Hidroksil Tanin Kulit Buah Kakao pada Pewarnaan Sutera, Jurnal Industri Hasil Perkebunan . vol. 4 No. 1 . Makassar, 2009.

[6] Sri Mulato, S. Widyantomo, Misnawati dan E. Suharyanto, Petunjuk Teknis Pengolahan Produk Primer dan Sekunder Kakao. Jurnal. Universitas Jember, 2005.

[7] Westendarp, Effects of tannins in animalnutrition. Dtsch. Tierarztl, Wochensch, 2006, p. 264-268. 